\title{
Kontribusi Motivasi Kerja dan Peran Kepala Sekolah Terhadap Profesionalisme Guru SMA
}

\author{
Nurkolis Siri Kastawi \\ Universitas PGRI Semarang \\ nurkolis@gmail.com \\ Agus Nugroho \\ Universitas PGRI Semarang \\ suganugraha80@gmail.com \\ Noor Miyono \\ Universitas PGRI Semarang \\ noormyn@gmail.com
}

\begin{abstract}
This study aims to determine the contribution of teacher work motivation to teacher professionalism, the principal's contribution to teacher professionalism, and the contribution of work motivation and the role of school principals to teacher professionalism. The population of the study was all civil servant teachers in SMA Negeri Salatiga with number of population 209 people and the sample are 131 people. The samples were chosen by using proportional random sampling technique. Data collection was done by distributing questionnaire and hypothesis testing with regression. The results showed, (1) there was a positive and significant contribution $t$ of work motivation on teacher professionalism of $92.2 \%$, (2)there was a positive and significant contribution of the role of the principal on the teacher professionalism of $90.2 \%$, and (3) there was a positive and significant contribution of work motivation and the role of the principal on professionalism teachers at 93.1\%. It is hoped that further research will find out other factors that contribute ot teacher professionalism.
\end{abstract}

Keywords: Teacher Professionalism, Principal's Role, Work Motivation

\section{Article Info}

\section{PENDAHULUAN}

Pendidikan merupakan proses yang sangat strategis dalam mencerdaskan kehidupan bangsa, sehingga harus dilakukan secara profesional. Oleh sebab itu guru sebagai salah satu pelaku pendidikan haruslah seorang yang profesional. Dengan demikian keberadaan guru di dalam proses pendidikan dapat bermakna bagi masyarakat dan bangsa. Kebermaknaan guru bagi masyarakat akan mendorong penghargaan yang lebih baik dari masyarakat kepada guru. Guru menjadi agen perubahan bagi keberadaan sebuah bangsa yang beradab dan memiliki tata nilai yang positif.

$$
\text { Menurut Mulyasa (2011, p. 38) }
$$
kompetensi diartikan sebagai pengetahuan, 
keterampilan, dan kemampuan yang dikuasai oleh seseorang yang telah menjadi bagian dari dirinya, sehingga ia dapat melakukan perilaku kognitif, afektif dan psikomotorik dengan sebaik baiknya.

Undang-Undang Republik Indonesia Nomor 14 Tahun 2005 Tentang Guru Dan Dosen, Pasal 1 ayat (1) dengan tegas menjelaskan bahwa guru adalah tenaga professional dengan tugas utama mendidik, mengajar, membimbing, mengarahkan, melatih, menilai dan mengevaluasi peserta didik pada pendidikan anak usia sekolah pada jalur pendidikan formal, pendidikan dasar dan pendidikan menengah. Begitu pula menurut Undang-Undang Republik Indonesia Nomor 20 Tahun 2003 Tentang Sistem Pendidikan Nasional, pasal 39 ayat (2), menyatakan bahwa pendidik merupakan tenaga professional yang bertugas merencanakan dan melaksanakan proses pembelajaran, menilai hasil pembelajaran, melakukan pembimbingan dan pelatihan serta melakukan penelitian dan pengabdian kepada masyarakat, terutama bagi pendidik pada perguruan tinggi.

Menurut Hamalik (2006, p. 36) guru profesional harus memiliki ketrampilan dasar mengajar yang baik, memahami atau menguasai bahan dan memilliki loyalitas terhadap tugasnya. Guru harus memiliki 4 kompetensi yaitu: kompetensi pedagogik, kompetensi profesional, kompetensi sosial dan kompetensi kepribadian. Kompetensi profesional menekankan pada pengetahuan dan wawasan yang cukup tentang isi mata pelajaran sehingga mutlak diperlukan untuk menciptakan proses pembelajaran yang baik. Penguasaan terhadap materi menjadi salah satu prasyarat untuk melaksanakan pembelajaran yang efektif, karena guru juga menjadi sumber pengetahuan bagi siswa.

Berdasarkan kompetensi profesionalnya tersebut guru harus memiliki profesionalisme dalam bekerja. Profesionalisme guru membantu dalam menyelesaikan tugas dan tanggung jawabnya. Untuk mengetahui profesionalisme guru dapat diamati dari hasil akhir pembelajaran siswa berupa capaian nilai ujian nasional, nilai ujian kompetensi guru yang bersangkutan, atau penilian kepala sekolah dan pengawas. Data faktual tersebut dapat dijadikan acuan untuk mengukur profesionalisme guru.

Berdasarkan laporan neraca pendidikan daerah (NPD) pada laman Kementrian Pendidikan dan Kebudayaan, data profesionalisme guru SMA di Kota Salatiga tahun 2017, nilai rata-rata UKG guru SMA di Kota Salatiga pada kompetensi profesional adalah 69,89 sedikit di bawah rata-rata nilai UKG nasional sebesar 70. Padahal berdasarkan Rencana Pembangunan Jangka Menengah Nasional (RPJMN) capaian nilai UKG terus mengalami kenaikan yaitu 75 di tahun 2018 dan 80 di tahun 2019 (htpps://beritagar.id, diakses tanggal 23 Mei 2019).

Peningkatan profesionalisme guru sangatlah esensial. Menyadari akan peran guru dalam pendidikan, Syah (2013, p. 45) mengemukakan bahwa guru dalam pendidikan modern seperti sekarang bukan hanya sekedar pengajar melainkan harus menjadi direktur belajar. Artinya, setiap guru diharapkan untuk pandai-pandai mengarahkan kegiatan belajar siswa agar mencapai keberhasilan belajar (kinerja akademik) sebagaimana telah ditetapkan dalam sasaran kegiatan pelaksanaan belajar mengajar. Sebagai konsekuensinya tugas dan tanggung jawabnya menjadi lebih kompleks. Perluasan tugas dan tanggung jawab tersebut membawa konsekuensi timbulnya fungsi-fungsi khusus yang menjdi bagian integral dalam kompetensi profesionalisme keguruan yang disandang para guru. Menanggapi kondisi tersebut, Syah (2013, p. 250) mengutip pendapat Gagne bahwa setiap guru berfungsi sebagai (a) designer of intruction (perancang pengajaran), (b) manager of intruction (pengelola pengajaran), (c) evaluator of student learning (penilai prestasi belajar siswa). 
Berdasarkan laporan neraca pendidikan daerah (NPD) pada laman Kementrian Pendidikan dan Kebudayaan, data profesionalisme guru SMA di Kota Salatiga tahun 2017, nilai rata-rata UKG guru SMA di Kota Salatiga pada kompetensi profesional adalah 69,89 sedikit di bawah rata-rata nilai UKG nasional sebesar 70. Padahal berdasarkan Rencana Pembangunan Jangka Menengah Nasional (RPJMN) capaian nilai UKG terus mengalami kenaikan yaitu 75 di tahun 2018 dan 80 di tahun 2019 (htpps://beritagar.id, diakses tanggal 23 Mei 2019). Menurut penelitian Khairussaleh (2017) motivasi kerja guru di Kota Salatiga sudah baik yaitu pada rerata 88 . Sementara itu peran kepala sekolah di Kota Salatiga sudah tinggi (Sari, 2016).

Berdasarkan hasil-hasil penelitian motivasi kerja guru dan peran kepala sekolah memiliki kontribusi terhadap profesionalisme guru. Menurut Darmawan (2017), motivasi kerja guru merupakan salah salah satu faktor yang memengaruhi profesionalisme guru. Hasil penelitian Rida, M., Dantes, N., (2013) menyatakan terdapat kontribusi signifikan antara motivasi kerja dengan profesionalisme guru. Peran kepala sekolah dalam mengembangkan profesionalisme guru adalah sebagai penanggung jawab (Aryani, 2017). Kepala sekolah memiliki banyak peran dalam mengembangkan profesionalisme guru (Asmui, Sudirman, 2019). Kepala sekolah memiliki peran ganda yaitu peran administrative dan supervisi (Lazwardi, 2016). Kepala sekolah memiliki banyak peran dalam meningkatkan profesionalisme guru yaitu sebagi administrator, supervisor, manajer, dan motivator (Sari, 2015). Namun terdapat beberapa kendala dalam peningkatan profesionalisme guru oleh kepala sekolah (Berliani, T., \& Wahyuni, 2017). Menurut Tanama, Y.J., Supriyanto, A., \& Burhanuddin (2016) peran kepala sekolah sebagai supervisor dapat meningkatkan profesionalisme guru.
Berdasarkan deskripsi latar belakang masalah tersebut maka rumusan masalah dalam artikel ini adalah (a) apakah terdapat kontribusi motivasi kerja terhadap profesionalisme guru SMA Negeri di Kota Salatiga, (b) apakah terdapat kontribusi peran kepala sekolah terhadap profesionalisme guru SMA Negeri di Kota Salatiga, dan apakah terdapat kontribusi motivasi kerja dan peran kepala sekolah secara simultan terhadap profesionalisme guru SMA Negeri di Kota Salatiga?

Dengan demikian tujuan dari penelitian ini adalah (a) untuk mengetahui kontribusi motivasi kerja terhadap profesionalisme guru SMA Negeri di Kota Salatiga, (b) untuk mengetahui kontribusi peran kepala sekolah terhadap profesionalisme guru SMA Negeri di Kota Salatigam dan (c) untuk mengetahui kontribusi motivasi kerja dan peran kepala sekolah secara simultan terhadap profesionalisme guru SMA Negeri di Kota Salatiga.

\section{Profesionalisme Guru}

Profesionalisme guru adalah suatu sikap yang dapat dilihat dari kompetensi yang dimilikinya. Profesionalisme guru meningkat apabila yang bersangkutan juga meningkatkan kompetensi yang dimilikinya. Sesuai dengan SNP, guru memiliki 4 kompetensi yang harus melekat pada dirinya, meliputi: kompentensi pedagogik, kompetensi profesional, kompetensi kepribadian dan kompetensi sosial. Kompetensi kepribadian dan kompetensi sosial dapat diamati dari perilaku guru dan bagaimana guru tersebut berhubungan dengan orang lain, sedangkan kompetensi pedagogik dan kompetensi profesional didapat dari capaian guru dalam bidang pengajaran. Profesionalisme guru mencakup semua kompetensi yang sudah ada di dalam pribadi guru utamanya yang terlihat adalah kompetensi profesionalnya.

Usman (2009, p. 17) menyatakan bahwasanya guru yang mempunyai kompetensi profesional adalah guru yang mempunyai ciriciri seperti berikut: menguasai landasan 
pendidikan, menguasai bahan pengajaran, menyusun program pengajaran, melaksanakan program pembelajaran yang telah disusun, dan menilai hasil program pelajaran yang dilaksanakan. Guru yang kompeten akan lebih mampu menciptakan lingkungan belajar yang efektif, menyenangkan, dan lebih mampu mengelola kelasnya, sehingga proses belajar mengajar menjadi optimal.

Uno (2008, pp. 18-19) menyatakan kemampuan professional guru adalah seperangkat kemampuan yang harus dimiliki oleh seorang guru agar ia dapat melaksanakan tugas mengajar. Adapun kompetensi profesional mengajar yang harus dimiliki oleh seorang yaitu meliputi kemampuan dalam merencanakan, melaksanakan, dan mengevaluasikan sistem pembelajaran, serta kemampuan dalam mengembangkan sistem pembelajaran.

Menurut Sudjana (2010, p. 19) dimensi profesionalisme guru adalah sebagai berikut: a) Perencanaan pembelajaran, yang meliputi tujuan, materi alokasi wakktu, metode dan prsedur, media dan sumber belajar, serta teknik penilaian dalam pembelajaran. b) Pelaksanaan pembelajaran, yang meliputi tentang membuka pelajaran, penyajian dan metode, penggunaan media dan sumber belajar, memberikan kesimpulan, serta penggunaan waktu. c) Penilaian pembelajaran, yang meliputi penyusunan soal, pengolahan dan analisis, laporan dan tindak lanjut. d) Tindak lanjut pembelajaran, yang meliputi identifikasi kesulitan belajar, penyusunan dan pelaksanaan perbaikan dan pengayaan, serta evaluasi dan analisis program.

Muslim (2010, p. 114) menyatakan sebagai suatu profesi, guru yang memiliki profesionalisme, ditandai oleh hal-hal berikut ini: guru mempunyai komitmen pada siswa dan proses belajarnya, guru menguasai secara mendalam bahan atau materi yang akan diajarkannya serta cara mengajarkannya kepada siswa, guru bertanggung jawab 80 memantau hasil belajar siswa, melalui berbagai teknik evaluasi, guru mampu berfikir sistematis tentang apa yang dilakukannya dan belajar dari pengalamannya (harus ada waktu bagi guru untuk mengadakan refleksi dan koreksi terhadap apa yang telah dilakukannya), dan guru seyogiyanya merupakan bagian dari masyarakat belajar dalam lingkungan profesinya.

Guru yang profesional diharapkan mampu melaksanakan tugasnya secara lebih baik. Tugas utama seorang guru adalah mengajar/mendidik. Untuk dapat melaksanakan tugas tersebut dengan baik, seorang guru sesungguhnya telah dibekali dengan sejumlah kompetensi, yakni kompetensi sosial, kompetensi personal, dan kompetensi profesional. Dari ketiga kompetensi di atas, kompetensi profesional merupakan salah satu kompetensi terpenting dan paling menentukan bagi keefektifan pelaksanaan tugas guru yaitu mengajar.

Berdasarkan Peraturan Menteri Pendayagunaan Aparatur Negara Dan Reformasi Birokrasi Nomor 16 Tahun 2009 Tentang Jabatan Fungsional Guru Dan Angka Kreditnya, pasal 1 ayat 2, guru adalah tenaga profesional dengan tugas utama mendidik, mengajar, membimbing, mengarahkan, melatih, menilai, dan mengevaluasi hasil pembelajaran, menyusun dan melaksanakan program perbaikan dan pengayaan terhadap peserta didik. Selain tugas utamanya tersebut, dalam menunjang profesionalismenya, guru dituntut mengembangkan kompetensinya melalui pengembangan keprofesian berkelanjutan (PKB). Sebagaimana ayat 5 dikatakan pengembangan keprofesian berkelanjutan adalah pengembangan kompetensi guru yang dilaksanakan sesuai kebutuhan bertahap, berkelanjutan untuk meningkatkan profesionalismesnya.

Pengembangan Keprofesian

Berkelanjutan adalah bagian penting dari proses peningkatan profesionalisme guru yang 
merupakan tanggung jawab secara individu kepada masyarakat. Pengembangan profesionalisme guru melalui PKB sebagaimana pasal 11 Permen PAN RB No.16 tahun 2009 dapat dilaksanakan secara terkait melalui: pengembangan diri, penyusunan publikasi ilmiah, dan karya inovasi.

Berdasarkan uraian di atas maka dimensi profesionalisme guru yang digunakan dalam penelitian ini adalah: perencanaan, pelaksanaan, penilaian, tindak lanjut pembelajaran, pengembangan diri, dan publikasi ilmiah yang dilakukan oleh guru untuk menunjang profesionalismenya.

Indikator profesionalisme guru dalam penelitian ini didasarkan pada dimensi perencanaan, pelaksanaan, penilaian dan tindak lanjut pembelajaran, pengembangan diri, dan publikasi ilmiah yang dilakukan oleh guru untuk menunjang profesionalismenya.

Profesionalisme guru dalam penelitian ini mendasarkan pada Undang-Undang Republik Indonesia Nomor 14 Tahun 2005 Tentang Guru Dan Dosen, Bab 1 Pasal 1 Ayat 1 yang menyatakan guru merupakan pendidik professional dengan tugas utama mendidik, mengajar, membimbing, mengarahkan, melatih, menilai, dan mengevaliasi peserta didik. Indikator dalam proses pembelajaran aspek yang diukur dalam penelitian ini meliputi: perencanaan, pelaksanaan, penilaian, dan tindak lanjut pembelajaran. Perencanaan pembelajaran meliputi; tujuan, materi ajar, alokasi waktu, metode dan prosedur, media dan sumber belajar, dan teknik penilaian. Pelaksanaan pembelajaran dalam bentuk mengorganisasikan kegiatan interaksi belajar mengajar yang meliputi; teknik membuka pelajaran, penyajian metode, penggunaan media dan sumber belajar, simpulan pembelajaran, dan ketepatan penggunaan waktu pembelajaran. Penilaian atau evaluasi pembelajaran meliputi; penyusunan soal, pengolahan dan analisis soal, pelaporan hasil belajar. Tindak lanjut pembelajaran meliputi; identifikasi kesulitan belajar, penyusunan dan pelaksanaan program perbaikan dan pengayaan, evaluasi, analisisi program, dan membuat rujukan kepada ahli lain.

Berdasarkan hal tersebut dapat disimpulkan bahwa profesionalisme guru adalah komitmen guru dalam meningkatkan kemampuan kompetensi di bidang pengajaran dalam rangka melaksanakan tugas keprofesiannya. Dimensi dalam penelitian ini adalah: perencanaan, pelaksanaan, penilaian, tindak lanjut pembelajaran, pengembangan diri, dan publikasi ilmiah.

Indikator perencanaan meliputi menyusun perangkat pembelajaran sebagaimana silabus dan kurikulum, mempersiapkan media/alat pembelajaran, dan menyusun teknik penilaian. Indikator pelaksanaan meliputi: teknik memulai pembelajaran, penguasaan materi pembelajaran. Indikator penilaian meliputi: menyusun instrumen penilaian kategori HOTS, melaksanakan penilaian, menganalisis hasil penilaian. Indikator tindak lanjut meliputi: mengidentifikasi kesulitan belajar, mendokumentasikan kegiatan pembelajaran, melaksanakan program pengayaan dan remidiasi. Indikator pengembangan diri meliputi: diklat fungsional, kegiatan kolektif guru melalui seminar atau forum guru. Indikator publikasi ilmiah meliputi, menyusun modul pembelajaran, dan melakukan penelitian atau pembuatan karya tulis ilmiah (KTI). Faktafakta empiris tersebut mengambarkan masih lemahnyanya profesionalisme guru SMA Negeri di Kota Salatiga.

\section{Motivasi Kerja Guru}

Motivasi kerja guru adalah semangat dari pribadi guru yang mendorong seorang guru menjalankan tugasnya dengan baik dan penuh tanggung jawab. Motivasi kerja dapat timbul dari dalam diri yang bersangkutan ataupun dari kontribusi lingkngan kerja dimana guru tersebut menjalankan profesionalismenya. Guru dengan motivasi kerja yang tinggi, akan 
bekerja tidak sekedar memenuhi tugas dan tanggung jawabnya sebagai keadaan aman di zona nyaman, melainkan dedikasi yang tinggi untuk mencerdaskan anak didiknya dan memotivasi dirinya untuk meningkatkan jenjang karier dan menjalankan tugas dan kewajibannya itu dengan ikhlas.

Siagian (2012, p. 7) mengatakan, motivasi kerja adalah keseluruhan proses pemberian motif bekerja kepada bawahan sedemikian rupa sehingga mereka mau bekerja dengan ikhlas untuk mencapai tujuan. Timbulnya motivasi pada diri seseorang ditentukan oleh adanaya kebutuhan hidup baik kebutuhan primer maupun sekundernya. Jika kebutuhan tersebut dapat dipenuhi, maka seseorang akan giat bekerja dan dapat meningkatkan motivasi kerjanya. Motivasi merupakan kondisi atau energi yang menggerakkan diri secara terarah atau tertuju untuk mencapai tujuan organisasi. Sikap mental guru yang pro dan positif terhadap situasi kerja itulah yang memperkuat motivasi kerjanya untuk mencapai kinerja maksimal.

Turunnya motivasi kerja dapat disebabkan beberapa faktor antara lain; sikap mental dari guru yang bersangkutan, rasa malas dengan selalu menunda-nunda pekerjaan, persaingan antar pegawai yang kurang baik, hubungan kerja yang tidak harmonis, perlakuan diskriminatif kepala sekolah, tidak adanya pembagian tugas tambahan secara adil dan proporsional, ketiakpedulian sekolah pada jenjang karir guru, dan pemberian tugas mengajar yang tidak sesuai dengan bidang keahliannya.

Motivasi kerja setiap orang berbeda, kuat atau lemahnya motivasi tergantung pada keadaan diri seseorang yang pasti bahwa motivasi pada diri setiap orang memiliki ciriciri sebagai berikut: tekun menghadapi tugas (dapat menerus dalam waktu yang lama, tidak pernah berhenti sebelum selesai), ulet menghadapi kesulitan (tidak lekas putus asa), menunjukkan minat terhadap bermacam- macam masalah, lebih senang bekerja sendiri, cepat bosan pada tugas-tugas yang rutin (halhal yang bersifat mekanis, berulang-ulang begitu saja, sehingga kurang kreatif, dapat mempertahankan pendapatnya (kalau sudah yakin akan sesuatu), tidak pernah mudah melepaskan hal yang diyakini, dan senang mencari dan memecahkan masalah soal-soal.

Mangkunegara (2001, p. 103) mengemukakan bahwa karakteristik sesorang yang mempunyai motivasi kerja tinggi adalah: memiliki tingkat kemauan yang tinggi, tanggung jawab terhadap pekerjaan, berani mengambil resiko dan merealisasikan rencana kerja yang telah diprogramkan.

Herzberg, Mausner dan Snyderman mengadakan studi tentang motivasi kerja Robbins, S.P., \& Judge (2007, p. 172). Berdasarkan studi tersebut, Herzberg dan kawan-kawan merumuskan teori motivasi yang disebut dengan Teori Dua Faktor. Teori ini dikenal juga dengan teori Motivator Hygienes. Herzberg memisahkan dua faktor yaitu: faktor "Motivasional" (bersifat intrinsik), yaitu hal-hal yang mendorong berprestasi yang sifatnya instrinsik yang berarti bersumber dalam diri seseorang dan faktor dan faktor "Hygiene" (bersifat ekstrinsik) yaitu faktorfaktor yang sifatnya ekstrinsik yang berarti bersumber dari luar diri yang turut menentukan prilaku seseorang dalam kehidupannya. Kedua faktor dapat mempengaruhi seseorang dalam bekerja. Termasuk faktor motivasional adalah prestasi yang dicapai, pengakuan, dunia kerja, tanggung jawab, dan kemajuan. Termasuk ke dalam faktor pemeliharaan adalah hubungan interpersonal antara atasan dan bawahan, teknik supervisi, kebijakan administratif, kondisi kerja, dan kehidupan pribadi.

Secara umum Usman (2009, p. 86) membedakan motivasi menjadi dua, yaitu motivasi yang timbul dari dalam diri individu disebut motivasi intrinsik, dan motivasi yang timbul dari luar diri individu disebut motivasi ekstrinsik. Hamalik (2006, p. 75) juga membagi 
motivasi dalam dua jenis yaitu motivasi intrinksik dan motivasi ekstrinksik. Sejalan dengan pendapat tersebut, Malone dalam Uno (2008, p. 72) juga membedakan dua bentuk motivasi yang meliputi motivasi intrinksik dan motivasi ekstrinksik.

Maka dari uraian diatas disimpulkan bahwa seseorang yang memiliki motivasi kerja akan memiliki ciri-ciri sebagaimana tersebut di atas. Ciri-ciri motivasi seperti itu akan sangat penting dalam kegiatan belajar mengajar. Karena kegiatan belajar mengajar akan berhasil baik, kalau gurunya tekun melaksanakan pekerjaannya, ulet dalam memecahkan masalah dan hambatan secara mandiri. Guru yang produktif tidak akan terjebak pada sesuatu yang rutinitas. Selain itu, juga harus berani mempertahankan pendapatnya kalau memang yakin dan rasional. Bahkan peka dan responsive terhadap berbagai masalah umum dan berfikir menantang serta mencari cara pemecahannya.

Berdasarkan uraian di atas dimensi motivasi kerja dalam penelitian ini dibagi menjadi dua yaitu dimensi motivasi kerja intrinsik yang timbul dari diri guru dan motivasi kerja ekstrinsik yang berasal dari faktor luar guru (lingkungan kerja).

Frederich Hersberg dalam Sedarmayanti (2007, p. 75) menyatakan pada manusia berlaku faktor motivasi dan faktor pemeliharaan di lingkungan pekerjaannya. Dari hasil penelitiannya menyimpulkan faktor motivasi yaitu: prestasi, pengakuan, kemajuan/kenaikan pangkat, pekerjaan itu sendiri, kemungkinan untuk tumbuh, tanggung jawab. Sedangkan untuk pemeliharaan terdapat sepuluh faktor yang perlu diperhatikan, yaitu kebijaksanaan, supervisi teknis, hubungan antar manusia dengan atasan, hubungan manusia dengan pembinanya, hubungan antar manusia dengan bawahannya, gaji dan upah, kestabilan kerja, kehidupan pribadi, kondisi tempat kerja dan status.

Hasibuan (2013: 183) menyatakan bahwa motivasi kerja merupakan dorongan atau rangsangan yang diperoleh untuk melakukan aktivitas atau kegiatan di tempat kerja untuk mencapai tujuan baik yang berasal dari dalam maupun dari luar diri yang dicirikan dengan adanya disiplin, semangat kerja, ambisi, kompetisi dan kerja keras.

Menurut Siagian (2012, p. 294) motivasi dipengaruhi oleh beberapa faktor, baik yang bersifat internal maupun eksternal. Yang termasuk faktor internal adalah: persepsi seseorang mengenai diri sendiri; harga diri; harapan pribadi; kebutuhan; keinginan; kepuasan kerja; prestasi kerja yang dihasilkan. Sedangkan faktor eksternal yang mempengaruhi motivasi seseorang antara lain: jenis dan sifat pekerjaan; kelompok kerja dimana seseorang bergabung; organisasi tempat orang bekerja; situasi lingkungan kerja; dan gaji.

Sedangkan menurut Uno (2008, p. 112) seorang yang memiliki motivasi kerja akan tampak melalui tanggung jawab dalam melakukan kerja, prestasi yang dicapainya, pengembangan diri, dan kemandirian dalam bertindak.

Berdasarkan uraian di atas motivasi kerja adalah dorongan dari diri seseorang baik dari dalam diri sendiri maupun lingkungan sekitar sebagai suatu kebutuhan yang membuatnya semangat dalam mencapai harapan dan tujuan dalam bekerja, maka penelitian ini mengambil dua dimensi tentang motivasi kerja yaitu motivasi yang timbul dari dalam diri guru sendiri disebut motivasi intrinsik dan motivasi karena faktor lingkungan disebut motivasi ekstrinsik.

Indikator motivasi intrinsik meliputi: tanggung jawab dalam melaksanakan pekerjaan, melaksanakan pekerjaan dengan target yang jelas, memiliki tujuan yang jelas dan menantang, terdapat umpan balik terhadap pekerjaan, memiliki perasaan senang dalam bekerja, dan indikator motivasi ekstrinsik meliputi: selalu berusaha berkompetisi dalam pekerjaan, mengutamakan prestasi kerja, 
berusaha memenuhi kebutuhan hidup dan kebutuhan kerja, senang memperoleh pujian, senang memperoleh penghargaan, dan bekerja dengan harapan memperoleh perhatian dari teman.

\section{Peran Kepala Sekolah}

Faktor lain yang mempengaruhi profesionalisme guru selain motivasi kerja adalah peran kepala sekolah, peran kepala sekolah. Menurut Wahjosumidjo (2011, p. 82), kepala sekolah adalah seorang guru yang diangkat untuk memduduki jabatan struktural di sekolah yang ditugaskan untuk mengelola sekolah. Kepala sekolah memegang peranan penting dalam mempengaruhi dan mengarahkan porsonil sekolah yang ada, agar dapat bekerjasama dalam mencapai tujuan sekolah. Kepala sekolah memiliki peran sebagai pemimpin di sekolahnya dan bertanggung jawab dan memimpin proses pendidikan di sekolahnya, yang berkaitan dengan peningkatan mutu sumber daya manusia, peningkaan profesionalisme guru, karyawan dan semua yang berhubungan dengan sekolah dibawah naungan kepala sekolah. Peran kepala sekolah sebagai pemimpin mencerminkan tanggung jawab kepala sekolah untuk menggerakkan sumber daya yang ada di sekolah.

Selain sebagai pemimpin kepala sekolah juga berperan sebagai pendidik (edukator). Sebagai pendidik,kepala sekolah dapat memberikan pembelajaran kepada guru bagaimana menguasai modelmodelpembelajaran sehingga KBM bisa berjalan efektif. Mengajarkan kepada guru bagaimana menyusun perangkat pembelajaran yang benar. Sehingga kepala sekolah menjadi suri tauladan bagi warga sekolah yang dipimpinnya, termasuk menguasai tugas umum guru. Perilaku kepala sekolah dalam menjalankan perannya berdampak pada peningkatan profesionalisme guru. Sebagaimana menurut Mulyasa (2011, p. 98) kepala sekolah sedikitnya memiliki peran sebagai edukator, manajer, administrator, supervisor, leader, inovator, motivator dan enterprenuer (EMASLIME).

Peran kepala sekolah SMA di Salatiga sebagai motor penggerak peningkatan profesionalisme guru belumlah optimal. Hal ini disadari karena peran kepala sekolah lebih terlihat dalam peranan administrasi atau birokratis. Terlebih kepala sekolah belum berperan aktif ketika melihat guru yang terkendala naik pangkat karena tidak memiliki unsur pengembangan diri, publikasi ilmiah, dan karya inovasi sebagai syarat pengembangan profesi berkelanjutan yang harus dimilikinya. Ironisnya fakta menunjukan bahwa pada bulan Mei 2018 terdapat salah satu kepala sekolah SMA Negeri di Kota Salatiga yang didemo siswanya dan mendapat mosi tidak percaya dari sebagian guru karena ketidakcakapan dalam mengelola sekolah (Tribun Jateng.com, Jumat, 8 Juni 2018).

Menurut Suhardiman (2010, p. 2) kepala sekolah adalah seorang yang dianut di suatu sekolah, dalam menjalankan perannya, seorang kepala sekolah tentu saja harus mampu membuat perencanaan yang sistematis, terpadu, berkelanjutan dan komprehensif. Target utama perencanaan dalam pendidikan adalah tercapainya tujuan pendidikan secara efektif dan efisien dengan mutu pendidikan yang memuaskan para pelanggan atau stakeholdernya.

Kaitannya dengan peran kepala sekolah Wahjosumidjo (2011, p. 90) ada tiga macam peranan kepala sekolah dilihat dari otoritas dan status formal seorang pemimpin. Kegitanya adalah peran hubungan antarperseorangan (Interpersonal Roles), peran Informasional (Informatiaonal Roles), dan peran pengambil keputusan (Desicional Roles). Menurut Karwati, E., \& Priansa (2013, p. 116) tugas profesional kepala sekolah adalah sebagai educator, manager, administrator, supervisor, leader, inovator, dan motivator atau disingkat dengan EMASLIM. 
Berdasarkan definisi tentang peran kepala sekolah adalah suatu perilaku yang dimiliki oleh kepala sekolah yang harus dijalankan sesuai dengan kedudukan sebagai kepala sekolah dengan segala tugas dan tanggungjawabnya untuk mencapai tujuan sekolah, memiliki beberapa dimensi diantaranya kepala sekolah sebagai: interpersonal roles, informational roler,descisional roles, educator, manager, administrator, supervisor, leader, inovator, dan motivator. Dimensi peran kepala sekolah yang sesuai dengan profesionalisme guru dalam penelitian ini adalah sebagai educator, manager, supervisor, inovator, dan motivator.

Berdasarkan definisi tentang peran kepala sekolah adalah suatu perilaku yang dimiliki oleh kepala sekolah yang harus dijalankan sesuai dengan kedudukan sebagai kepala sekolah dengan segala tugas dan tanggungjawabnya untuk mencapai tujuan sekolah, memiliki beberapa dimensi diantaranya kepala sekolah sebagai: interpersonal roles, informational roler,descisional roles, educator, manager, administrator, supervisor, leader, inovator, dan motivator. Dimensi peran kepala sekolah yang sesuai dengan profesionalisme guru dalam penelitian ini adalah sebagai educator, manager, supervisor, inovator, dan motivator.

Indikator peran kepala sekolah dalam penelitian ini adalah sebagai edukator meliputi; menguasai bimbingan dan bantuan kepada guru,mampu mengembangkan kemampuan guru dalam kegiatan kolektif dan diklat fungsional, kompeten dan professional dalam tugas pokok guru; sebagai manajer meliputi; memahami visi misi dan menyusun program, menyusun administrasi sekolah, melaksanakan kegiatan supervise, melaksanakan pemgambilan keputusan dan kebijakan, menjadi tauladan dan memililiki kepemimpinan yang baik; sebagai supervisor kepala sekolah harus memiliki kemampuan program supervisi pendidikan, kemampuan melaksanakan program supervisi pendidikan yang baik serta kemampuan memanfaatkan hasil supervisi pendidikan; sebagai inovator memiliki inovasi dan gagasan dalam pengembangan tata ruang sekolah, pengembangan model-model pembelajaran, pengembangan kewirausahaan; dan sebagai motivator mampu memotivasi dan menginspirasi guru dalam jenjang karir, prestasi kerja dan membangun jejaring.

\section{METODE PENELITIAN}

Pendekatan penelitian ini adalah kuantitatif dengan desain korelasional. Penelitian dilakukan di SMA Negeri di Kota Salatiga Provinsi Jawa Tengah yang terdiri dari 3 SMAN yaitu SMAN 1,2, dan 3 Salatiga. Waktu penelitian bulan Mei 2019 hingga September 2019. Populasi 209 orang, sampel 131 orang, sampling menggunakan propotional random sampling. Populasi SMAN 1 Salatiga 76 orang dan sampel 48, SMAN 2 Salatiga dengan populasi 69 orang dan sampel 43 orang, serta SMAN 3 Salatiga dengan populasi 64 orang diambil sampel 40 orang. Penentuan jumlah sampel menggunakan rumus Slovin dengan tingkat kepercayaan 95\%. Teknik pengumpulan data menggunakan angket dengan lima alternatif jawaban yaitu sangat setuju (ss), setuju (s), kurang setuju (ks), tidak setuju (ts) dan sangat tidak setuju (sts). Angket dikirim langsung ke sekolah-sekolah untuk dapat diisi oleh para guru yang menjadi responden.

Variabel penelitian terdiri dari satu variable terikat $(\mathrm{Y})$ dan dua variable bebas $(\mathrm{X})$. Variabel terikatnya adalah profesionalisme guru, variabel bebas pertama (x1) adalah motivasi kerja guru, dan variabel bebas kedua (x2) adalah peran kepala sekolah. Variabel motivasi kerja terdiri dari 2 dimensi yang selanjutnya dirinci menjadi 11 indikator yang selanjutnya dituangkan menjadi 35 pernyataan. Variabel peran kepala sekolah terdiri dari 5 dimensi yang selanjutnya dirinci menjadi 12 
indikator dan dituangkan ke dalam 40 pernyataan. Sedangkan variabel profesionalisme guru terdiri dari 6 dimensi dan dirinci lagi menjadi 14 indikator yang selanjutkan dinyatakan ke dalam 42 pernyataan.

Instrumen penelitian berupa angket sudah layak digunakan kerena telah dilakukan uji validitas item butir dan reliabilitas variabel. Hasil uji validitas item butir untuk variabel motivasi kerja sebanyak 34 pernyataan valid dan 1 pernyataan tidak valid. Hasil uji validitas item butir variabel peran kepala sekolah 38 butir pernyataan valid dan 2 tidak valid. Hasil uji validitas item butir variabel profesionalisme guru sebanyak 39 valid dan 3 tidak valid. Semua butir pernyataan yang tidak valid tidak digunakan sebagai instrumen penelitian final. Hasil uji reliabilitas variabel motivasi kerja sebesar 0,937, peran kepala sekolah sebesar 0,940, dan profesionalisme guru sebesar 0,939. Reliabilitas ketiga variabel tersebut semuanya di atas 0,6 yang artinya ketiga variabel tersebut reliabel.

Setelah data terkumpul diolah dengan program SPPS versi 25. Uji prasyarat menggunakan uji normalitas, linieritas, homogenitas, dan heteroskedastisitas yang hasilnya menunjukkan bahwa uji hipotesis bisa menggunakan statistik parametrik. Oleh karena itu uji hipotesis yang digunakan adalah uji anova dan uji regresi tunggal dan berganda.

\section{HASIL PENELITIAN DAN PEMBAHASAN}

\section{Hasil Penelitian}

Hasil pengukuran variabel profesionalisme guru dengan jarak interval 17 diperoleh nilai rata-rata 156,18 , nilai tengah 158.00 , nilai yang sering muncul 156 , standar deviasi 21,09, nilai minimum sebesar 103 dan nilai maksimum 187. Variabel profesionalisme guru dibagi dalam 5 kategori yaitu sangat tinggi, tinggi, cukup tinggi, rendah dan sangat rendah. Pengelompokan ini dimaksudkan untuk menentukan posisi skor rata-rata profesionalisme guru. Skor rata-rata profesionalisme guru 156,18 terletak pada interval 154-170 termasuk pada kategori tinggi. Maka dapat disimpulkan bahwa profesionalisme guru SMA Negeri di Kota Salatiga dikategorikan tinggi.

Tabel 1. Tabel 1. Data Deskriptif Variabel Penelitian

\begin{tabular}{lccc}
\hline \multicolumn{1}{c}{ Deskripsi } & Profesionalisme Guru & Motivasi Kerja & Peran Kepala Sekolah \\
\hline $\mathrm{N}$ & 131 & 131 & 131 \\
\hline Mean & 156.18 & 136.65 & 151.44 \\
\hline Median & 158.00 & 139.00 & 151.00 \\
\hline Mode & $156^{\mathrm{a}}$ & $143^{\mathrm{a}}$ & $149^{\mathrm{a}}$ \\
\hline Std. Deviation & 21.093 & 18.986 & 20.682 \\
\hline Minimum & 103 & 91 & 100 \\
\hline Maximum & 187 & 165 & 184
\end{tabular}

Sumber: Data penelitian

Hasil pengukuran terhadap variabel motivasi kerja dengan jarak interval 15 diperoleh hasil nilai mean 136,65 , nilai median 139.00, nilai mode 143, standar deviasi 18,99, nilai minimum sebesar 91 dan nilai maksimum sebesar 165. Variabel motivasi kerja dikelompokkan dalam 5 kategori yaitu sangat tinggi, tinggi, cukup tinggi, rendah dan sangat rendah. Skor rata-rata variabel motivasi kerja 86
136,65 yang terletak pada interval 109-122 masuk pada kategori tinggi. Maka dapat disimpulkan bahwa motivasi kerja guru SMA Negeri di Kota Salatiga dikategorikan tinggi.

Hasil pengukuran terhadap peran kepala sekolah dengan jarak interval 17 diperoleh hasil nilai rata-rata 151,44 , nilai tengah 151.00 , nilai yang sering muncul 149, standar deviasi 20,68, nilai minimum sebesar 100 dan nilai maksimum 
sebesar 184. Variabel peran kepala sekolah dibagi ke dalam 5 kategori yaitu sangat baik, baik, cukup baik, kurang dan sangat kurang. Skor rata-rata atau mean peran kepala sekolah 151,44 yang terletak pada interval 151-167 masuk pada kategori baik. Maka dapat disimpulkan bahwa peran kepala sekolah SMA Negeri di Kota Salatiga dikategorikan baik.

\section{Kontribusi Motivasi Kerja Terhadap Profesionalisme Guru}

Pengujian kontribusi motivasi kerja terhadap profesionalisme guru dapat dilihat pada tabel berikut ini.

Tabel 2. Uji Anova Pengaruh Motivasi Kerja terhadap Profesionalisme Guru

\begin{tabular}{lccccc}
\hline \multicolumn{1}{c}{ Model } & Sum of Squares & Df & Mean Square & F & Sig. \\
\hline Regression & 53376.960 & 1 & 53376.960 & 1543.640 & $.000^{\mathrm{b}}$ \\
Residual & 4460.644 & 129 & 34.579 & & \\
Total & 57837.603 & 130 & & & \\
\hline
\end{tabular}

a. Dependent Variable: Profesionalisme_Guru

b. Predictors: (Constant), Motivasi_Kerja

Sumber: Output SPSS versi 25

Berdasarkan perhitungan sebagaimana tabel di atas hasil uji Anova motivasi kerja terhadap profesionalisme guru dapat dijelaskan bahwa hasil analisis regeresi diperoleh nilai signifikansi $0,000<0,05$. Sedangkan nilai $F_{\text {hitung }}$ sebesar 1543,640 $>F_{\text {tabel }}$ 3,92 sehingga hipotesis pertama $\left(\beta_{\mathrm{X} 1 \mathrm{y}} \neq 0\right)$ yang berbunyi terdapat kontribusi motivasi kerja terhadap profesionalisme guru SMA Negeri di Kota Salatiga diterima.

Kemudian untuk mengetahui besarnya kontribusi motivasi kerja terhadap profesionalisme guru dapat dilihat pada tabel berikut ini.

Tabel 3. Besar Pengaruh Motivasi Kerja terhadap Profesionalisme Guru

\begin{tabular}{ccccc} 
Model & $\mathrm{R}$ & R Square & Adjusted R Square & Std. Error of the Estimate \\
\hline 1 & $.961^{\mathrm{a}}$ & .923 & .922 & 5.880 \\
\hline
\end{tabular}

a. Predictors: (Constant), MOTIVASI_KERJA

Sumber: Output SPSS versi 25

Dari hasil uji regresi linier tunggal seperti tabel di atas dapat dijelaskan bahwa kontribusi motivasi kerja terhadap profesionalisme guru diperoleh nilai Adjusted $R$ square sebesar 0,922 artinya bahwa $92,2 \%$ profesionalisme guru mendapatkan kontribusi dari motivasi kerja, sisanya 7,8\% variabel bebas lainnya. Berikut hasil koefisien regresi motivasi kerja terhadap profesionalisme guru.

Tabel 4. Koefisien Regresi Motivasi Kerja terhadap Profesionalisme Guru

\begin{tabular}{lccccc}
\hline \multicolumn{1}{c}{ Model (1) } & Sum of Squares & Df & Mean Square & F & Sig. \\
\hline (Constant) & 10.344 & 3.747 & & 2.760 & .007 \\
MOTIVASI_KERJA & 1.067 & .027 & .961 & 39.289 & .000 \\
\hline
\end{tabular}

a. Dependent Variable: PROFESIONALISME_GURU

Sumber: Output SPSS versi 25

Berdasarkan tabel uji regresi motivasi kerja terhadap profesionalisme guru diperoleh hasil nilai konstanta 10,344 dan nilai koefisien regresi sebesar 1,067 dengan signifikansi 0,000 sehingga persamaan regresi sebagai berikut: $\hat{Y}$
$=10,344+1,067 \mathrm{X}_{1}$. Persamaan tersebut dapat dijelaskan sebagai berikut. Angka 10,344 artinya jika motivasi kerja dianggap konstan maka profesionalisme guru mempunyai nilai sebesar 10,344. Angka 1,067 menunjukkan 
koefisien regresi positif, artinya apabila motivasi kerja semakin baik maka profesionalisme guru juga meningkat.

Kontribusi Peran Kepala Sekolah Terhadap Profesionalisme Guru
Pengujian kontribusi peran kepala sekolah terhadap profesionalisme guru dapat dilihat pada tabel 5. Selanjutnya untuk mengetahui hipotesis diterima atau ditolak, maka dapat dilihat dari hasil uji anova sebagaimana tabel di bawah ini.

\section{Tabel 5. Uji Anova Peran Kepala Sekolah terhadap Profesionalisme Guru}

\begin{tabular}{lccccc}
\hline Model (1) & Sum of Squares & Df & Mean Square & F & Sig. \\
\hline Regression & 52206.061 & 1 & 52206.061 & 1195.868 & $.000^{\text {b }}$ \\
Residual & 5631.542 & 129 & 43.655 & & \\
Total & 57837.603 & 130 & & & \\
\hline a. Dependent Variable: PROFESIONALISME_GURU & & \\
b. Predictors: (Constant), PERAN_KS & & & \\
Sumber: Output SPSS versi 25 & & & \\
\hline
\end{tabular}

Berdasarkan perhitungan sebagaimana tabel di atas hasil uji Anova peran kepala sekolah terhadap profesionalisme guru dapat dijelaskan bahwa hasil analisis regeresi diperoleh nilai signifikansi $0,000<0,05$. Sedangkan nilai $F_{\text {hitung }}$ sebesar 1195,868 $>F_{\text {tabel }}$ 3,92 sehingga hipotesis kedua $\left(\beta_{\mathrm{X} 2 \mathrm{y}} \neq 0\right)$ yang berbunyi terdapat kontribusi peran kepala sekolah terhadap profesionalisme guru SMA Negeri di Kota Salatiga diterima.

Untuk mengetahui besarnya kontribusi peran kepala sekolah terhadap profesionalisme guru dapat dilihat pada tabel di bawah ini.

Tabel 6. Pengaruh Peran Kepala Sekolah terhadap Profesionalisme Guru

\begin{tabular}{lcccc}
\hline Model & R & R Square & Adjusted R Square & Std. Error of the Estimate \\
\hline 1 & $.950^{\mathrm{a}}$ & .903 & .902 & 6.607 \\
\hline a. Predictors: (Constant), PERAN_KS \\
Sumber: Output SPSS versi 25
\end{tabular}

Dari hasil uji regresi linier tunggal seperti tabel di atas dapat dijelaskan bahwa kontribusi peran kepala sekolah terhadap profesionalisme guru diperoleh nilai Adjusted $R$ square sebesar 0,902 artinya bahwa 90,3\% profesionalisme guru karena kontribusi peran kepala sekolah, sisanya $9,8 \%$ variabel bebas lainnya. Berikut hasil koefisien regresi budaya kerja terhadap profesionalisme guru.

Tabel 7. Koefisien Regresi Peran Kepala Sekolah terhadap Profesionalisme Guru

\begin{tabular}{lccccc}
\hline & \multicolumn{3}{c}{ Unstandardized Coefficients } & & \\
\cline { 2 - 6 } Model (1) & $\mathrm{B}$ & Std. Error & Standardized Coefficients Beta & $\mathrm{t}$ & Sig. \\
\hline (Constant) & 9.444 & 4.282 & & 2.205 & .029 \\
PERAN_KS & .969 & .028 & .950 & 34.581 & .000 \\
\hline
\end{tabular}

a. Dependent Variable: PROFESIONALISME_GURU

Sumber: Output SPSS versi 25

Berdasarkan tabel uji regresi peran kepala sekolah terhadap profesionalisme guru diperoleh hasil nilai konstanta 9,444 dan nilai koefisien regresi sebesar 0,969 dengan signifikansi $0 ., 00$ sehingga persamaan regresi 88 sebagai berikut: $\hat{\mathrm{Y}}=9,444+0,969 \mathrm{X}_{2}$. Persamaan tersebut dapat dijelaskan sebagai berikut. Angka 9,444 artinya jika peran kepala sekolah dianggap konstan maka profesionalisme guru mempunyai nilai sebesar 
9,444. Angka 0,969 menunjukkan koefisien regresi positif, artinya apabila peran kepala sekolah semakin baik maka profesionalisme guru juga meningkat.

Kontribusi Motivasi Kerja dan Peran Kepala Sekolah Terhadap Profesionalisme Guru
Hasil uji regresi linier berganda yaitu kontribusi motivasi kerja dan peran kepala sekolah secara bersama-sama terhadap profesionalisme guru dapat dilihat pada tabel Anova sebagai berikut.

Tabel 8. Uji Anova Motivasi Kerja dan Peran Kepala Sekolah terhadap Profesionalisme Guru

\begin{tabular}{lcccccc}
\hline Model (1) & Sum of Squares & Df & & Mean Square & F & Sig. \\
\hline Regression & 53894.805 & 2 & 26947.403 & 874.827 & $.000^{\mathrm{b}}$ & Regression \\
Residual & 3942.798 & 128 & 30.803 & & & Residual \\
Total & 57837.603 & 130 & & & & Total \\
\hline
\end{tabular}

a. Dependent Variable: PROFESIONALISME_GURU

b. Predictors: (Constant), PERAN_KS, MOTIVASI_KERJA

Sumber: Output SPSS versi 25

Berdasarkan perhitungan hasil uji Anova motivasi kerja dan peran kepala sekolah terhadap profesionalisme guru dapat dijelaskan bahwa hasil analisis regeresi diperoleh nilai signifikansi $0,000<0,05$. Sedangkan nilai $F_{\text {hitung }}$ sebesar 874,827 $>\mathrm{F}_{\text {tabel }}$ 3,92 sehingga hipotesis ketiga $\left(\beta X_{12 y} \neq 0\right)$ yang berbunyi terdapat kontribusi motivasi kerja dan peran kepala sekolah terhadap profesionalisme guru SMA Negeri di Kota Salatiga diterima.

Untuk mengetahui besarnya kontribusi motivasi kerja dan peran kepala sekolah terhadap profesionalisme guru dapat dilihat pada tabel di bawah ini.

Tabel 9. Hasil Regresi Linier Berganda

\begin{tabular}{lcccc}
\hline Model & R & R Square & Adjusted R Square & Std. Error of the Estimate \\
\hline 1 & $.965^{\text {a }}$ & .932 & .931 & 5.550 \\
\hline a. & Predictors: (Constant), PERAN_KS, MOTIVASI_KERJA \\
Sumber: Output SPSS versi 25 & \\
\hline
\end{tabular}

Dari hasil uji regresi linier berganda di atas dapat dijelaskan bahwa kontribusi motivasi kerja dan peran kepala sekolah terhadap profesionalisme guru diperoleh nilai Adjusted $R$ square sebesar 0,931 artinya bahwa $93,1 \%$ profesionalisme guru karena kontribusi motivasi kerja dan peran kepala sekolah, sisanya $6,9 \%$ pada variabel bebas lainnya. Berikut hasil koefisien regresi linier berganda.

Tabel 10. Hasil Koefisien Regresi Linier Berganda

\begin{tabular}{lccccc}
\hline & \multicolumn{2}{l}{ Unstandardized Coefficients } & & & \\
\cline { 2 - 5 } \multicolumn{1}{c}{ Model (1) } & $\mathrm{B}$ & Std. Error & Standardized Coefficients Beta & $\mathrm{t}$ & Sig. \\
\hline (Constant) & 7.432 & 3.607 & & 2.060 & .041 \\
MOTIVASI_KERJA & .696 & .094 & .627 & 7.404 & .000 \\
PERAN_KS & .354 & .086 & .347 & 4.100 & .000 \\
\hline a. Dependent Variable: PROFESIONALISME_GURU & & & \\
Sumber: Output SPSS versi 25 & & & & \\
\hline
\end{tabular}

Berdasarkan tabel uji regresi linier berganda diperoleh hasil nilai konstanta 7,432 dan nilai koefisien regresi sebesar 0,696 untuk motivasi kerja dan 0,354 untuk peran kepala sekolah dengan signifikansi 0,000 sehingga persamaan regresi sebagai berikut: $\hat{Y}=7,432+$ 0696X $\mathrm{X}_{1}+0,354 \mathrm{X}_{2}$. Persamaan tersebut dapat dijelaskan sebagai berikut. Angka 7,432 artinya 
jika motivasi kerja dan peran kepala sekolah dianggap konstan maka profesionalisme guru mempunyai nilai sebesar 7,432. Angka 0,696 menunjukkan koefisien variabel motivasi kerja dan angka 0,354 menunjukkan koefisien variabel peran kepala sekolah, kedua koefisien nilainya positif, artinya apabila motivasi kerja dan peran kepala sekolah semakin baik maka profesionalisme guru juga meningkat.

\section{Pembahasan}

\section{Kontribusi Motivasi Kerja Terhadap} Profesionalisme Guru. Dapat disimpulkan bahwa naik turunnya profesionalisme guru karena baik buruknya kontribusi motivasi kerja. Semakin baik motivasi kerja maka semakin meningkat profesionalisme guru. Demikian pula sebaliknya jika motivasi kerja tidak baik, maka profesionalisme guru akan menurun.

Hasil penelitian ini sejalan dengan penelitian Sulistyawati (2016) yang menunjukkan motivasi kerja berkontribusi positif signifikan terhadap kinerja guru. Demikian pula penelitian Tetuko (2012) yang menyatakan bahwa motivasi kerja guru mempengaruhi kepuasan kerja yang selanjutnya mendorong kinerja guru. Agar memiliki kinerga tinggi maka guru terlebih dahulu harus profesional. Profesionalisme guru yang tinggi salah satunya karena kontribusi faktor motivasi kerja guru. Demikian juga halnya dengan penelitian Dewi \& Anggia (2015) yang menunjukan bahwa profesionalisme guru dan motivasi kerja memiliki kontribusi positif dan signifikan terhadap kinerja guru.

Kontribusi Peran Kepala Sekolah Terhadap Profesionalisme Guru. Maka dapat disimpulkan bahwa naik turunnya profesionalisme guru karena kontribusi baik buruknya peran kepala sekolah. Kepala sekolah memiliki kontribusi yang besar terhadap profesionalisme guru sehingga guru akan melaksanakan pekerjaannya sesuai tugas dan fungsinya. Semakin baik peran kepala sekolah maka semakin meningkat profesionalisme 90 guru. Demikian pula sebaliknya jika peran kepala sekolah tidak baik, maka profesionalisme guru akan menurun.

Hasil penelitian ini sejalan dengan penelitian Bakhruddin (2016) yang menyatakan bahwa kepala sekolah memiliki peran untuk meningkatkan profesinalisme guru sehingga memiliki kecenderungan untuk menghasilkan pengelolaan sekolah yang efektif. Demikian pula penelitian Sepriadi \& Ahamd (2017) serta Tetuko (2012) bahwa peran kepala sekolah sebagai pemimpin berkontribusi secara signifikan terhadap kinerja guru sehingga tinggi rendahnya kualitas kepemimpinan kepala sekolah akan berkontribusi terhadap tinggi rendahnya kinerja guru. Agar guru dapat berkinerja tinggi maka guru tersebut harus profesional dan peran kepala sekolah sangat menentukannya.

Kontribusi Motivasi Kerja dan Peran Kepala Sekolah Terhadap Profesionalisme Guru. Dapat disimpulkan bahwa naik turunnya profesionalisme guru karena baik buruknya kontribusi motivasi kerja dan peran kepala sekolah. Semakin baik motivasi kerja dan peran kepala sekolah maka semakin meningkat profesionalisme guru. Demikian pula sebaliknya jika motivasi kerja dan peran kepala sekolah tidak baik, maka profesionalisme guru akan menurun.

Hasil penelitian ini mendukung hasil penelitian sebelumnya yang dilakukan oleh Dewi \& Anggia (2015) dan Tetuko (2012) bahwa motivasi kerja guru dan peran kepala sekolah memiliki kontribusi yang besar dalam peningkatan kinerja guru. Demikian pula hasil penelitian Bakhruddin (2016) serta Sepriadi \& Ahamd (2017) bahwa motivasi kerja guru dan peran kepala sekolah berkontribusi positif terhadap profesionalisme guru.

Motivasi kerja dan peran kepala sekolah terhadap guru memberikan makna yang positif. Motivasi kerja sebagai perilaku positif yang mengerakkan semangat bekerja dan kepala sekolah yang memahami akan perannya 
sebagai pembina guru secara langsung di sekolah dapat berkontribusi dalam meningkatkan profesionalisme guru.

\section{SIMPULAN DAN SARAN}

\section{Simpulan}

Berdasarkan pada hasil penelitian dan pembahasan dapat diambil kesimpulan sebagai berikut. Pertama, terdapat kontribusi positif dan signifikan motivasi kerja terhadap profesionalisme guru sebesar 92,2\%, sisanya $7,8 \%$ karena kontribusi faktor lain. Pengaruh positif ini berarti bahwa jika motivasi kerja semakin tinggi maka profesionalisme guru meningkat. Kedua, terdapat kontribusi positif dan signifikan peran kepala sekolah terhadap profesionalisme sebesar $90,2 \%$, sisanya $9,8 \%$ karena kontribusi faktor lain. Kontribusi positif ini berarti bahwa jika peran kepala sekolah semakin baik maka profesionalisme guru meningkat. Ketiga, terdapat kontribusi positif dan signifikan motivasi kerja dan peran kepala sekolah terhadap profesionalisme guru sebesar $93,1 \%$, sisanya sebesar $6,9 \%$ karena kontribusi faktor lain.

\section{Saran}

Berdasarkan hasil penelitian, maka peneliti memberikan beberapa saran sebagai berikut. Pertama, Dinas Pendidikan Provinsi memberikan pembinaan kepada kepala sekolah agar meningkatkan perannya sebagai supervisor dan inovator dalam meningkatkan profesionalisme guru. Selain itu Dinas Pendidikan Provinsi memberikan penguatan tentang pentingnya motivasi ekstrinsik (motivasi karena faktor lingkungan) bagi guru agar terbangun kesadaran dalam peningkatan profesionalisme guru. Kedua, kepala sekolah disarankan untuk meningkatkan tugas supervisi kepada guru secara berkala khususnya supervisi klinis sehingga dapat mengetahui hambatanhambatan yang dialami oleh guru dalam melaksanakan tugas keprofesiannya. Kepala sekolah juga disarankan untuk memberikan contoh atau tauladan melakukan inovasi dalam pembelajaran yang dapat dikembangkan oleh guru sehingga meningkatkan profesionalitasnya. Ketiga, guru disarankan agar dapat meningkatkan proses pembelajaran di kelas dengan menggunakan metode yang inovatif dan menyenangkan sehingga dapat meningkatkan profesionalismenya. Guru juga disarankan dapat mengikuti kegiatan ilmiah atau kegiatan kolektif lainnya semacam seminar atau In House Training (IHT) sebagai usaha pengembangan diri untuk meningkatkan profesionalismennya. Disarankan kepada peneliti lain untuk melakukan penelitian serupa di tempat lain atau jenjang pendidikan yang berbeda, atau melakukan penelitian lanjutan terkait peningkatan profesionalisme guru.

\section{DAFTAR PUSTAKA}

Aryani, R. (2017). Kepemimpinan Kepala Sekolah Dalam Pengembangan Profesionalisme Guru. Al-Afkar: Jurnal Ilmu Keislaman dan Peradaban. AlAfkar: Jurnal Ilmu Keislaman Dan Peradaban, 5(1), 107-128. https://doi.org/https://doi.org/10.28944/ afkar.v5i1.135.

Asmui, Sudirman, \& S. (2019). Peran Kompetensi Manajerial Kepala Sekolah Dalam Peningkatan Profesionalisme Guru. Jurnal Ilmiah Profesi Pendidikan, 4(1), 61-66. https://doi.org/https://doi.org/10.29303/ jipp.v4i1.81.

Bakhruddin, M. (2016). Peran Kepala Sekolah Dalam Memberdayakan Tenaga Pendidik (Key Concept of Leadership Roles at SMA Negeri 16 and SMA Muhammadiyah 2, Surabaya). Islam Komtemporer: Jurnal Studi Keislaman, 1(1).

Berliani, T., \& Wahyuni, R. (2017). Implementasi Supervisi Oleh Kepala Sekolah Dalam Meningkatkan Profesionalisme Guru. Manajemen Dan Supervisi Pendidikan, 1(3), 218-226. 
https://doi.org/https://doi.org/10.17977/ um025v1i32017p218

Darmawan, I. (2017). Faktor Yang Mempengaruhi Profesionalitas Guru. http://www.semnas.sttsimpson.ac.id/in dex.php/SNPK/article/view/19

Dewi, \& Anggia, T. (2015). Pengaruh Profesionalisme Guru Dan Motivasi Kerja Terhadap Kinerja Guru Ekonomi SMA Se-Kota Malang. Jurnal Promosi Jurnal Pendidikan Ekonomi UM Metro, 3(1), 24-35.

Hamalik, O. (2006). Pendidikan Guru Berdasarkan Pendekatan Kompetensi. PT. Remaja Rosdakarya.

Karwati, E., \& Priansa, D. J. (2013). No Title. Alfabeta.

Khairussaleh. (2017). Pengaruh Supervisi Kelompok dan Komunikasi Interpersonal Pengawas Terhadap Kinerja Guru PAI Dengan Motivasi Kerja Sebagai Variabel Intervening (Studi Di Kota Salatiga Tahun 2017). IAIN Salatiga.

Lazwardi, D. (2016). Peran Kepala Sekolah Dalam Meningkatkan Profesionalisme Guru. Jurnal Kependidikan Islam, 6(2), 139-157.

https://doi.org/https://doi.org/10.24042/ alidarah.v6i2.804

Mangkunegara, \& Prabu, A. (2001). Manajemen Sumber Daya Manusia Perusahaan. PT Remaja Rosdakarya.

Mulyasa, E. (2011). Manajemen Berbasis Sekolah. PT Remaja Rosdakarya.

Muslim, \& S. B. (2010). Supervisi Pendidikan Meningkatkan Kualitas Profesionalisme Guru. Alfabeta.

Peraturan Menteri Pendayagunaan Aparatur Negara dan Reformasi Birokrasi Nomor
16 tahun 2009 tentang Jabatan fungsional Guru dan Angka Kreditnya.

Rida, M., Dantes, N., \& D. K. . (2013). Hubungan Motivasi Kerja, Masa Kerja Dan Kesejahteraan Guru Terhadap Profesionalisme Guru Sekolah Dasar Negeri Di Gugus Ii Kecamatan Sukasada. Jurnal Pendidikan Dasar Ganesha, 3(1).

Robbins, S. P., \& Judge, T. A. (2007). Perilaku Organisasi. Alih Bahasa oleh Diana Angelina. Salemba Empat.

Sari, H. (2016). Kepemimpinan Yang Melayani Di Sekolah Menengah Tingkat Atas Swasta Kota Salatiga. Kelola: Jurnal Manajemen Pendidikan, 3(2), 265-276.

Sedarmayanti. (2007). Manajemen SDM Cetakan 1. PT. Refika Aditama.

Sepriadi, \& Ahmad, S. (2017). Pengaruh Peran Kepala Sekolah Sebagai Supervisor Akademik Terhadap Kinerja Guru Di SMK PGRI Tanjung Raja. JMPKS. Jurnal Manajemen, Kepemimpinan, Dan Supervisi Pendidikan, 2(1), 55-76.

Siagian, S. P. (2012). Kiat Meningkatkan Produktivitas Kerja. Asdi Mahasatya.

Sudjana, N. (2010). Dasar-dasar Proses Belajar. Sinar Baru.

Suhardiman, B. (2010). Study Pengembangan Kepala Sekolah. Rineka Cipta.

Sulistyawati, N. (2016). Pengaruh Profesionalisme dan Motivasi Kerja Terhadap Kinerja Guru dengan Lingkungan Kerja Sebagai Variabel Moderasi (Studi Pada SMP Negeri Se Kecamatan Boja Kabupaten Kendal). Dharma Ekonomi, 23(43), 44-52.

Syah, M. (2013). Psikologi Pendidikan dengan Pendekatan Baru. Remaja Rosdakarya.

Tanama, Y.J., Supriyanto, A., \& B. (2016). Implementasi Supervisi Klinis Dalam 
Kontribusi Motivasi Kerja dan Peran Kepala Sekolah Terhadap Profesionalisme Guru SMA | Nurkolis, dkk.

Meningkatkan Profesionalisme Guru. Jurnal Pendidikan: Teori, Penelitian, \& Pengembangan, $1(11)$. https://doi.org/http://dx.doi.org/10.1797 7/jp.v1i11.8127.

Tetuko, B. (2012). Pengaruh Motivasi Kerja, Budaya Organisasi, Kepemimpinan Kepala Sekolah Terhadap Kepuasan Kerja dan Kinerja Guru SMA Swasta di Kabupaten Grobogan. Jurnal Educational Management, 1(2), 129134.

Undang-undang Republik Indonesia Nomor 14 tahun 2005 tentang Guru dan Dosen.
Undang-undang Republik Indonesia Nomor 20 tahun 2003 tentang Sistem Pendidikan Nasional.

Uno, H. B. (2008). Teori Motivasi dan Pengukurannya Analisis di Bidang Pendidikan. Bumi Aksara.

Usman, M. U. (2009). Menjadi Guru Profesional. PT Remaja Rosdakarya.

Wahjosumidjo. (2011). Kepemimpinan Kepala Sekolah: Tinjauan Teoritik dan Permasalahannya. PT. Raja Grafindo Persada. 